\title{
Regulasi emosi dan parenting stress pada ibu bekerja
}

\author{
Fathana Gina ${ }^{a, 1}$, Yulia Fitriani ${ }^{b, 2 *}$ \\ a,bFakultas Psikologi, Universitas Bhayangkara, Jakarta \\ 1fathana.gina@dsn.ubharajaya.ac.id; *2yulia1407fitriani@gmail.com \\ *Correspondent Author
}

KATAKUNCI

ibu bekerja; parenting stress; regulasi emosi

\section{KEYWORDS}

emotion regulation parenting stress; working mothers

\section{ABSTRAK}

Ibu dengan peran ganda atau dengan istilah ibu bekerja pada umumnya memiliki tanggung jawab yang lebih besar dibandingkan dengan ibu yang tidak bekerja. Oleh karena itu, peluang ibu bekerja untuk merasakan lelah baik secara fisik maupun emosional akan jauh lebih besar sehingga penting untuk mengetahui faktor yang memprediksi stress pada ibu bekerja. Penelitian ini bertujuan untuk melihat kontribusi regulasi emosi terhadap parenting stress pada ibu bekerja. Metode pada penelitian ini menggunakan metode kuantitatif korelasional. Subjek penelitian adalah ibu bekerja yang memiliki anak dengan total jumlah 318 orang. Penelitian menggunakan dua alat ukur, yaitu skala regulasi emosi dengan nilai koefisien reliabilitas 0,831 dan skala parenting stress dengan nilai koefisien reliabilitas 0,71 . Analisis data menggunakan teknik regresi sederhana dan diolah dengan menggunakan program SPSS 23 for windows. Hasil analisis data menunjukkan bahwa regulasi emosi mampu memprediksi parenting stress secara signifikan dengan nilai $\mathrm{F}=15.838$ dan $\mathrm{p}=0,000$ $(\mathrm{p}<0,001)$. Nilai $\mathrm{R}$ square 0,048 artinya regulasi emosi mampu memberikan sumbangan efektif terhadap parenting stress sebesar 4,8\%, sedangkan 95,2\% dipengaruhi oleh faktor lain. Penelitian ini menyimpulkan bahwa regulasi emosi secara signifikan mampu memprediksi parenting stress.

\section{Emotion regulation and parenting stress on working mothers}

Mothers with multiple roles or with the term working mothers generally have greater responsibilities than mothers who do not work. Therefore, the chances of working mothers to feel tired both physically and emotionally will be much greater, so it is important to know the factors that predict stress in working mothers. This study aims to see the contribution of emotional regulation to parenting stress in working mothers. The method in this study uses correlational quantitative methods. The research subjects were working mothers with children totaling 318 mothers. The study used two measuring instruments, Emotion Regulation Scale with a reliability coefficient of 0.831 and Parenting Stress Scale with a reliability coefficient of 0.71 . The data analysis used simple regression techniques and was processed using the SPSS 23 for windows program. The results of data analysis showed that emotional regulation was able to predict parenting stress significantly with a value of $F=15.838$ and $p=0.000(p<0.001)$. The $R$ square value of 0.048 means that emotional regulation effectively give contribution to parenting stress by $4.8 \%$, while $95.2 \%$ is influenced by other factors. This study concludes that emotion regulation is significantly able to 
predict parenting stress.

This is an open-access article under the CC-BY-SA license.

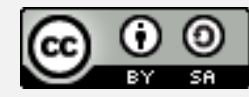

\section{Pendahuluan}

Keluarga merupakan fondasi pertama bagi perkembangan kepribadian dan tingkah laku anak. Anak dapat berkembang dengan optimal dan tumbuh menjadi individu yang berguna bagi sesama, salah satunya ditentukan oleh keberhasilan orangtua dalam mengasuh anak. Artinya, ketidaktahuan orangtua dalam mendidik dan mengasuh anak dengan baik dapat mengakibatkan anak tumbuh menjadi pribadi yang lemah dan kesulitan dalam bersosialisasi di masyarakat. Selanjutnya, di dalam budaya masyarakat Indonesia, bahwa tanggung jawab pengasuhan anak pada umumnya lebih banyak dibebankan kepada ibu. Peran ibu memiliki pengaruh besar dalam keluarga, karena ibu merupakan figur utama dan pertama yang dikenal anak sejak ia dilahirkan. Oleh sebab itu, ibu menempati posisi kunci dalam proses mengasuh dan mendidik anak. Meski di sisi lain, sebagian dari ibu di era yang semakin modern dan kebutuhan ekonomi yang semakin meningkat pada saat ini akhirnya membuat mereka juga mengambil pilihan untuk bekerja demi memenuhi tuntutan hidup.

Ibu dengan peran ganda sering dikenal dengan istilah ibu bekerja. Menurut Vureen (Apreviadizy \& Puspitacandri, 2014), ibu yang bekerja ialah ibu yang selain mengurus rumah tangga juga memiliki tanggung jawab di luar rumah, baik di kantor, yayasan, atau wiraswasta dengan kisaran waktu tidak banyak digunakan untuk keluarga (Munandar, dalam Apreviadizy \& Puspitacandri, 2014). Sebaliknya, ibu yang tidak bekerja adalah ibu yang tinggal di rumah dan cenderung melakukan tugas rumah tangga dalam kehidupan sehariharinya. Artinya, ibu dengan peran ganda adalah ibu yang mana waktu dan tanggung jawabnya tidak hanya untuk mengurus pekerjaan rumah dan mengasuh anak, namun juga ditambah dengan beban tugas di tempatnya bekerja.

Banyaknya tanggung jawab yang harus dipikul oleh ibu dengan peran ganda menyebabkan ibu berpeluang lebih banyak merasakan lelah, baik secara fisik maupun emosional. Selain itu, ketiadaan asisten rumah tangga yang dapat meringankan tugas ibu juga dapat menyebabkan ibu yang bekerja menjadi stres, karena dituntut untuk membagi waktu antara pekerjaan kantor dengan pekerjaan rumah. Begitupula, banyaknya pekerjaan di rumah dan di kantor, serta kurangnya manajemen waktu merupakan hal yang dapat memicu stres pada ibu bekerja (Yasmin, 2016).

Stres merupakan situasi yang biasa muncul dalam berbagai aspek kehidupan, tak terkecuali dalam pengasuhan anak. Ketika ibu yang memiliki peran besar dalam pengasuhan mengalami stres, maka sedikit banyak dapat mempengaruhi praktik pengasuhan yang dilakukannya. Kim (2015) dalam penelitiannya terhadap ibu bekerja menemukan bahwa konflik antara pekerjaan dan pengasuhan pada ibu bekerja berpengaruh secara tidak langsung terhadap parenting stress. Deater-Deckard (dalam Lestari, 2018) mendefinisikan parenting stress sebagai serangkaian proses yang membawa individu pada kondisi psikologis yang tidak disukai dan reaksi psikologis yang muncul dalam upaya beradaptasi dengan tuntutan peran sebagai orangtua. Dengan kata lain, parenting stress merupakan situasi penuh tekanan yang terjadi pada pelaksanaan tugas pengasuhan anak.

Perenting stress timbul ketika orang tua mengalami kesulitan dalam memenuhi tuntutan menjadi orang tua dan hal tersebut mempengaruhi perilaku, kesejahteraan, dan penyesuaian diri pada anak (Berry \& Jones, 1995). Penelitian yang dilakukan oleh Apreviadizy dan 
Puspitacandri (2014) menunjukkan bahwa ibu bekerja lebih banyak mengalami stres dibandingkan ibu tidak bekerja. Sejalan dengan hal tersebut, Maharrani (2019) juga menyebutkan adanya indikasi biologis untuk stres kronis pada ibu bekerja dengan dua anak, $40 \%$ lebih tinggi dibandingkan rekan kerja yang tidak memiliki anak. Menurut pendekatan P$\mathrm{C}-\mathrm{R}$, parenting stress bersumber dari tiga komponen, yaitu ranah orangtua $(\mathrm{P}$, adalah segala aspek stress pengasuhan yang muncul dari pihak orangtua); ranah anak ( $\mathrm{C}$, adalah segala aspek stress pengasuhan yang muncul dari perilaku anak); dan ranah hubungan orangtuaanak ( $R$, adalah segala aspek pengasuhan yang bersumber dari hubungan orangtua-anak).

Pada komponen orangtua, kesehatan fisik, mental dan emosi orangtua yang kurang baik dapat mendorong timbulnya stres. Ibu bekerja yang memiliki anak dimungkinkan memiliki parenting stress yang lebih tinggi dari pada ibu rumah tangga saja. Hal ini disebabkan karena tuntutan waktu, pikiran dan tenaga yang ekstra pada ibu dalam menjalankan kedua peran yang diembannya. Pada komponen anak juga dapat memicu parenting stress, misalnya kemampuan anak beradaptasi yang rendah, kurang penerimaan terhadap orangtua, suka menuntut atau menyusahkan, suasana hati yang buruk, mengalami kekacauan pikiran, dan kurang memiliki kemampuan untuk memperkuat orangtua. Adapun komponen relasi orangtua-anak yang dapat memicu parenting stress adalah derajat konflik yang muncul dalam interaksi orangtua anak. Dengan demikian, ketiga komponen tersebut pada akhirnya akan menyebabkan kemerosotan kualitas dan efektivitas perilaku pengasuhan (Lestari, 2018).

Ibu yang mengalami stres akan berdampak pada pengasuhan seperti berkata kasar, bersikap keras, tidak memberikan kasih sayang kepada anak, mengabaikan anak, menghukum anak. Hal tersebut merupakan pelampiasan emosi negatif dari tekanan yang dialami oleh ibu yang bekerja. Sementara luapan emosi negatif tersebut akan berdampak pada kesehatan fisik maupun psikis anak. Misalnya anak menjadi tertekan, terluka, bahkan sampai mengalami kematian. Oleh karena itu, keterampilan mengelola emosi atau regulasi emosi yang baik perlu dimiliki oleh ibu yang bekerja.

Regulasi emosi sendiri dijelaskan oleh Gross (1998) sebagai cara individu mengatur, merasakan atau mengekpresikan emosi yang mereka miliki. Gross dan Thompson (2007) mendefinisikan regulasi emosi sebagai proses pengenalan, pemeliharaan, dan pengaturan emosi yang terjadi secara langsung atau dikontrol, disadari atau tidak disadari. Menurut Thompson (dalam Garnefski, Kraaij, \& Spinhoven, 2001), regulasi emosi diasumsikan sebagai faktor penting dalam menentukan keberhasilan seseorang dalam usahanya untuk berfungsi dengan normal di kehidupannya seperti dalam proses adaptasi, dapat memberikan respon yang sesuai dan fleksibel.

Regulasi emosi yang dimaksud dalam penelitian ini adalah ibu yang bekerja mampu mengatur, merasakan dan mengespresikan emosi dalam mengasuh anaknya. Individu yang mampu meregulasi emosi dengan baik dapat mendatangkan kebahagiaan bagi diri mereka sendiri. Hal ini didukung oleh pendapat Mappiare (2003), yang menyatakan bahwa kebiasaan dalam meregulasi emosi mampu mendatangkan kebahagiaan dan kondisi psikis yang sehat bagi individu. Ketika ibu yang bekerja mampu mengelola emosi dengan baik, maka akan berdampak pada proses pengasuhan anaknya, salah satunya terhindar dari parenting stress.

Gross dan John (2003) menjelaskan bentuk besar strategi regulasi emosi, yaitu strategi regulasi emosi awal (antecedent-focused emotion regulation strategy) dan strategi regulasi emosi akhir (response-focused emotion regulation strategy). Model Gross dan John dapat dilihat pada gambar 1. 


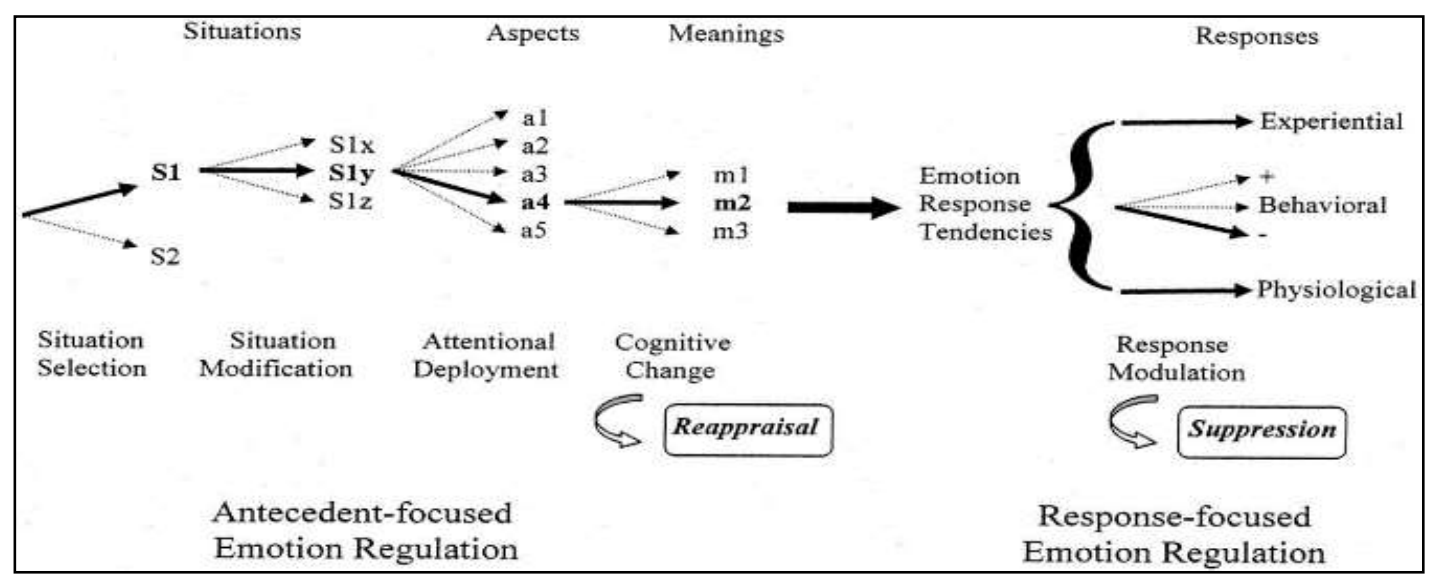

Gambar 1. Proses Model Regulasi Emosi (Gross \& John, 2003)

Strategi regulasi awal (antecedent-focused emotion regulation strategy) terdiri dari proses seleksi situasi, modifikasi situasi, penyebaran perhatian dan pengubahan kognitif. Bentuk dari strategi ini adalah reappraisal yang merupakan strategi kognitif dimana individu mampu berfikir positif terhadap berbagai situasi yang dihadapinya. Emosi merupakan salah satu keadaan afek selain stres, mood dan impuls, ketika seseorang mampu menilai kembali secara positif stimulus atau situasi yang sedang terjadi pada dirinya, dan hal tersebut juga akan meningkatkan afek positif pada dirinya. Dengan demikian dapat diasumsikan bahwa penilaian kembali secara kognitif (reappraisal) dapat menimbulkan emosi yang positif pada seseorang. Hal ini dapat membantu individu tetap merasa tenang dalam segala situasi, terutama situasi yang buruk atau tidak menyenangkan (Gross \& John, 2003; Gross \& Thompson, 2007).

Kedua, strategi regulasi emosi akhir (response-focused emotion regulation strategy) merupakan proses modulasi respon. Bentuk strategi ini adalah expression suppression dimana individu berusaha mengontrol dan menekan respon emosi yang tidak dapat diterima. Contohnya, ketika individu dihadapkan pada situasi yang tidak menyenangkan, maka individu akan diam saja atau menekan emosi tanpa mengubah pikiran negatif terhadap situasi tersebut (Gross \& John, 2003).

Berdasarkan penjelasan di atas, maka tujuan penelitian ingin mengetahui pengaruh regulasi emosi terhadap parenting stress pada ibu bekerja. Secara khusus penelitian ini diharapkan mampu berkontribusi pada pengembangan ilmu psikologi perkembangan dan psikologi industri organisasi. Selain itu, mampu menjadi rekomendasi bagi ibu bekerja untuk tetap mampu meregulasi emosi sehingga berdampak pada pengasuhan yang dilakukan.

\section{Metode}

Populasi pada penelitian ini adalah ibu bekerja yang memiliki anak. Teknik sampling yang digunakan dalam penelitian ini adalah purposive sampling, dengan jumlah sampel sebanyak 318 orang. Alat ukur yang digunakan adalah skala parenting stress dan skala regulasi emosi. Skala parenting stress dikembangkan oleh Berry dan Jones (1995), terdiri dari aspek parental rewards, parental stressors, lack of control, parental satisfaction. Daya diskriminasi aitem bergerak dari 0,336 sampai 0,631. Nilai koefisien reliabilitas skala parenting stress adalah $\mathrm{rtt}=0,831$. Contoh aitem skala parenting stress adalah sebagai berikut:

1. Saya senang dengan peran saya sebagai orang tua

2. Saya merasa memiliki anak menjadi suatu beban keuangan

3. Saya menikmati waktu yang dihabiskan bersama anak saya 
Skala regulasi emosi disusun oleh Gross dan John (2003), terdiri dari dua strategi yaitu reappraisal dan suppression. Adapun daya diskriminasi aitem bergerak dari 0,344 sampai 0,522 . Nilai koefisien reliabilitas skala regulasi emosi adalah $\mathrm{rtt}=0,71$. Contoh aitem skala regulasi emosi adalah sebagai berikut:

1. Supaya senang, saya memikirkan hal yang saya sukai

2. Jika saya sedih, saya diam saja

3. Jika sedang banyak pikiran, saya mencoba tenang.

Analisis data merupakan kegiatan lanjutan setelah pengumpulan data dilaksanakan. Pada penelitian ini menggunakan teknik analisis regresi sederhana atau simple regression analysis. Alasannya adalah penelitian ini ingin mengetahui apakah regulasi emosi dapat memprediksi parenting stress.

\section{Hasil}

Hasil uji hipotesis menunjukkan bahwa regulasi emosi mampu memprediksi parenting stress secara signifikan dengan nilai $F=15,838$ dan $\mathrm{p}=0,000(\mathrm{p}<0,001)$, sesuai dengan tabel 1 .

Tabel 1.

Uji Hipotesis

\begin{tabular}{llllll}
\hline Model & Sum of Squares & Df & Mean Square & $\boldsymbol{F}$ & Sig \\
\hline Regression & 796,312 & 1 & 796,312 & 15,838 &, 000 \\
Residual & $15.888,509$ & 316 & 50,280 & & \\
\hline Total & $16.684,821$ & 317 & & & \\
\hline
\end{tabular}

Hasil dari analisis data menunjukan terdapat korelasi antara regulasi emosi dan parenting stress dengan nilai koefisien korelasi atau $r=-0,218$ dengan nilai $p=0,00$ atau $\mathrm{p}<0,01$, sesuai dengan tabel 2. Menurut Periantalo (2016), nilai $r=-0,218$ termasuk dalam kategori korelasi yang lemah.

Tabel 2.

Hasil Uji Korelasi

\begin{tabular}{llll}
\hline & Regulasi Emosi & Parenting Stress \\
\hline Regulasi Emosi & Pearson Correlation & 1 &,$- 218^{* *}$ \\
& Sig (2-tailed) & &, 000 \\
$N$ & 318 & 318 \\
Parenting Stress & Pearson Correlation &,$- 218^{* *}$ & 1 \\
& Sig (2-tailed) &, 000 & \\
$N$ & 318 & 318 \\
\hline
\end{tabular}

Model persamaan regresi linier dilihat dari nilai koefisien konstanta dan koefisien regresi yang dapat dilihat pada tabel 3. Rumus persamaan regresi linier sederhana adalah $\mathrm{Y}=\mathrm{a}+\mathrm{bX}$. Persamaan regresinya adalah $\mathrm{Y}=52,193-0,355 \mathrm{X}$. Artinya setiap kenaikan $1 \%$ pada regulasi emosi akan menurunkan parenting stress sebesar 0,355.

Tabel 3.

Model Persamaan Regresi

\begin{tabular}{llllll}
\hline \multirow{2}{*}{ Model } & \multicolumn{2}{l}{ Unstandardized Coefficients } & Standardized Coeficient & \multirow{2}{*}{ S } & \multirow{2}{*}{ Sig } \\
\cline { 2 - 4 } & $\boldsymbol{B}$ & Std. Error & Beta & & \\
\hline (Constant) & 52.193 & 3.299 & & 15.821 &, 000 \\
Regulasi emosi &,- 355 &, 089 &,- 218 & -3.980 &, 000 \\
\hline
\end{tabular}


Nilai Rsquare sebesar 0,048 artinya regulasi emosi mampu memberikan sumbangan efektif terhadap parenting stress sebesar 4,8\%, sedangkan 95,2\% dipengaruhi oleh faktor lain, seperti pada tabel 4 .

Tabel 4 .

Sumbangan Efektif

\begin{tabular}{llllll}
\hline Model & $\boldsymbol{R}$ & R Square & $\begin{array}{l}\text { Adjusted } \boldsymbol{R} \\
\text { Square }\end{array}$ & $\begin{array}{l}\text { Std. Error of the } \\
\text { Estimate }\end{array}$ & Sig F Change \\
\hline 1 &, 218 &, 048 &, 045 & 7,091 &, 000 \\
\hline
\end{tabular}

\section{Pembahasan}

Penelitian ini bertujuan untuk mengetahui apakah regulasi emosi mampu memprediksi parenting stress pada ibu bekerja. Pengujian hipotesis menunjukkan bahwa regulasi emosi secara sangat signifikan mampu memprediksi parenting stress. Hal ini diketahui dengan hasil analisis regresi linier sederhana dengan nilai $F=15,838$ dan nilai $p=0,000 \quad(p<0,01)$. Berdasarkan hasil analisis dapat dijelaskan bahwa penelitian ini telah menjawab hipotesis yang diajukan. Regulasi emosi memberikan kontribusi terhadap parenting stress sebesar 4,8\% dan sisanya 95,2\% dipengaruhi oleh faktor lain yang tidak dilibatkan dalam penelitian ini. Sejalan dengan hasil tersebut, penelitian yang dilakukan oleh Ikasari dan Kristiana (2017) menemukan bahwa regulasi emosi memberikan sumbangan efektif sebesar 20,3\% terhadap stres pengasuhan ibu yang memiliki anak cerebral palsy.

Peran ganda yang dialami oleh ibu bekerja, dimana ibu memiliki tugas untuk mengurus anak, tugas rumah dan tugas kerja dapat menimbulkan kelelahan secara fisik maupun emosional yang dapat menyebabkan parenting stress. Hal tersebut dapat diminimalisir dengan cara meningkatkan keterampilan regulasi emosi. Individu yang memiliki keterampilan regulasi emosi yang baik, akan mampu menyeleksi situasi, memodifikasi situasi, dan fokus pada penyelesaian masalah, serta berpikir positif terhadap masalah yang sedang dihadapi (Gross \& John, 2003). Begitupula, ibu bekerja yang memiliki ketrampilan regulasi emosi yang baik mampu berpikir positif, tetap tenang dalam segala situasi, mampu memilih atau mengubah situasi agar menjadi lebih nyaman, dengan demikian ibu bekerja dapat terhindar dari stres dalam mengasuh anaknya. Sebaliknya, jika ibu bekerja memiliki keterampilan regulasi yang buruk, seperti merasa terbebani dengan tugas yang besar, tidak mampu berpikir positif, menilai situasi yang dialami sebagai suatu masalah besar, maka hal tersebut dapat memicu parenting stress yang tinggi pada ibu bekerja, dan berdampak pada pola pengasuhan, diantaranya menyakiti anak. Seperti yang disampaikan Hidayati (2013) melalui penelitiannya, bahwa pendampingan regulasi emosi dapat menurunkan maltreatment fisik yaitu perilaku mencubit ibu yang memiliki anak GPP/H.

Regulasi emosi diasumsikan sebagai faktor penting dalam menentukan keberhasilan seseorang dalam usahanya untuk berfungsi secara normal di kehidupannya seperti dalam proses adaptasi, dapat memberikan respon yang sesuai dan fleksibel (Thompson, dalam Garnefski, Kraaij, \& Spinhoven, 2001). Kemampuan regulasi emosi orangtua merupakan salah satu faktor yang dapat mempengaruhi parenting stress. Seperti yang dijelaskan oleh Lestari (2018), pada tingkatan orangtua, kesehatan fisik, mental, dan emosi orangtua yang kurang baik dapat menimbulkan parenting stress.

\section{Simpulan}

Berdasarkan hasil analisis data dapat disimpulkan bahwa penelitian ini telah menjawab hipotesis yang diajukan, yaitu regulasi emosi secara signifikan mampu memprediksi parenting stress. Regulasi emosi dapat memberikan kontribusi terhadap parenting stress 
sebesar 4,8\% dan sisanya 95,2\% dipengaruhi oleh faktor lain yang tidak dilibatkan dalam penelitian ini.

\section{DAFTAR PUSTAKA}

Apreviadizy, P., \& Puspitacandri, A. (2014). Perbedaan stres ditinjau dari ibu bekerja dan ibu tidak bekerja. Jurnal Psikologi Tabularasa, 9(1), 58-65. https://media.neliti.com/ media/publications/127612-ID-perbedaan-stres-ditinjau-dari-ibu-bekerj.pdf.

Berry \& Jones. (1995). The parental stres scale: Initial psychometric evidence. Sage Journals, 12(3). https://journals.sagepub.com/doi/10.1177/0265407595123009.

Fitriani, A., \& Ambarini, T. K. (2013). Hubungan antara hardiness dengan tingkat stres pengasuhan pada ibu dengan anak autis. Jurnal Psikologi Klinis dan Kesehatan Mental, 02(2). http://www.journal.unair.ac.id/download-fullpapers-jpkkc9b6c2dcddfull.pdf.

Garnefski, N., Kraaij, V., \& Spinhoven, P. (2001). Negative life events, cognitive emotion regulation and emotional problems. In Personality and Individual Differences (pp.13111327). file:///C:/Users/asus/Downloads/1887_14275Garnefski,_Kraaij\&amp\%3B_ Spinhoven1.pdf.

Gross, J. J. (1998). Antecedent-and response-focused emotion regulation: Divergent consequences for experiences, expression, and physiology. Journal of Personality and Social Psychology, 74(1), 224-237. https://sci-hub.se/10.1037//0022-3514.74.1.224.

Gross, J. J., \& John, O. P. (2003). Individual differences in two emotion regulation processes: Implications for affect, relationship, and well-being. Journal of Personality and Social Psychology, 85(2), 348-362. https://sci-hub.se/https://doi.org/10.1037/00223514.85.2.348.

Gross, J. J., \& Thompson, R. A. (2007). Emotion regulation: Conceptual foundations. In J. J. Gross (Ed.), Handbook of Emotion Regulation. New York: Guilford Press.

Harlinda, W. (2018). Hubungan antara dukungan sosial dan hardiness dengan stres pengasuhan pada ibu yang memiliki anak autis. Universitas Muhammadiyah Surakarta. http://eprints.ums.ac.id/61010/1/NASKAH\%20PUBLIKASI.pdf.

Hidayati, E. (2013). Peran pendampingan regulasi emosi terhadap perilaku maltreatment pada ibu dari anak GPP/H. Humanitas, 10(2). file://C:/Users/asus/Downloads/337368-1-PB.pdf.

Ikasari, A., \& Kristiana, I. F. (2017). Hubungan antara regulasi emosi dengan stres pengasuhan ibu yang memiliki anak Cerebral Palsy. Jurnal Empati, 6(4), 323-328. https://ejournal3.undip.ac.id/index.php/empati/article/view/20101/18971.

Kim, A. (2015). Study on the effect of working mom 's conflict between job and nurturing on parenting stress-focus on mediating effect of core competence in nurturing, (8 October). file:///C:/Users/asus/Downloads/Article81.pdf.

Lestari, S. (2018). Psikologi keluarga: Penanaman nilai dan penanganan konflik dalam keluarga (5th ed.). Jakarta: Prenadamedia Group.

Maharrani, A. (2019). Ibu bekerja 40 persen lebih stres. https://beritagar.id/artikel/gayahidup/ibu-bekerja-40-persen-lebih-stres.

Mappiare, A. (2003). Psikologi remaja. Surabaya: Usaha Nasional.

Periantalo, J. (2016). Penelitian kuantitatif untuk psikologi. Yogyakarta: Pustaka Pelajar.

Purnomo, J. C., \& Kristiana, I. F. (2016). Hubungan antara dukungan sosial suami dengan stres pengasuhan istri yang memiliki anak retardasi mental ringan dan sedang. Jurnal Empati, 5(3), 507-512. https://ejournal3.undip.ac.id/index.php/empati/article/view/ $15392 / 14884$.

Yasmin, P. A. (2016). Memahami Stres yang Rentan Dialami Ibu Bekerja. https://health.detik.com/ulasan-khas/d-3377897/memahami-stres-yang-rentandialami-ibu-bekerja. 